\title{
Factors Affecting the Treatment of Kenyan-Somalis and Somali Refugees in Kenya: A Historical Overview \\ Ogenga Otunnu
}

This paper is an attempt to explain the Kenyan authorities' inhumane treatment of Kenyan-Somalis and Somali refugees in terms of long-standing conflicts between Kenya and Somalia, and the Kenyan authorities' reaction to what they perceived as a "credible threat" from the North-Eastern Province. This long history of conflict and tension has created a distorted and hostile image of the Somalis as "enemies" of the Kenyan state. The image, real or imaginary, has continued to influence the Kenyan authorities' behaviour towards the Somalis, which has led to gross violations of human rights. ${ }^{1}$ This, however, is not an exhaustive explanation for the treatment of the two groups. Other variables, not directly examined here include the nature of the postcolonial state, the broader question of political legitimacy, the nature of the ruling class and the role of violence as a response to state repression.

In order to understand the development of this image anditsimplications for Kenyan Somalis and Somali refugees in Kenya, it is imperative to highlight some of the critical elements of the conflicts between the Kenyan government and the inhabitants of the North-Eastern Province of Kenya (which is the major part of what was formerly the Northern Frontier District), and between the Kenyan government and the government of Somalia. The conflict has its origins in the colonial era. At the turn of the century, Britain extended her control over this semiarid area. One of the foremost scholars on the region, A.A. Castagno, cites three reasons for this action: 1) to "provide a buffer between Italian Somaliland and Ethiopia on the one side, and the East African railway

Ogenga Otunnu is a doctoral candidate in the Department of History at York University and a Researcher in the Centre for Refugee Studies. and the white settlers in the highlands on the other"; 2) to deter the Ethiopian imperial power from annexing Boran and Gabro; and 3) to check "the Somali south-westward expansion."

To effect some of these policies and minimize ethnic and clan conflicts, administrative borders were redrawn, and in 1909 Somalis were not allowed beyond the Somali-Galla line. However, these policies caused Somali resistance to British colonialism to escalate. ${ }^{2}$ The colonial regime responded by declaring (through its Outlying District Ordinance) the Northern Frontier District (NFD) a closed district in 1926. By this draconian ordinance, colonial administrators were given sweeping powers to deal with any form of dissent or

\section{This long history of conflict and tension has created a distorted and hostile image of the Somalis as "enemies" of the Kenyan state.}

resistance. This was followed by the Special District Ordinance, which imposed severe restriction on movement to or from the "Special District." ${ }^{3}$ With this administrative control mechanism, Somalis were required to obtain special approval or passes to enter other provinces. It is clear, therefore, that this region did not generally share the same colonial experience with the rest of the country. To be precise, no serious attempt was made by the colonial regime to foster the socio-economic and political integration of this area into the rest of the country.

In a relentless attempt to address the grievances of the inhabitants of the area and revitalize the quest for Somali unity in eastern Africa, the Somali Youth League (SYL), founded in 1943 in Muqdisho, established itself in the NFD, the Ogaden region of Ethiopia and in British Somaliland. ${ }^{4}$ However, in keeping with the colonial response to the development of African nationalism in the country, political parties were banned in the NFD and the leadership of SYL was exiled between 1948 and 1960.

With the lifting of proscription on Somali parties in the area in 1960 and the unity between Somali and British Somaliland on July 1, 1960 to form the Somali Republic, the struggle for selfdetermination intensified in the NFD. The Northern Province People's Progressive Party, the Northern Province Democratic Party, the People's National League, and the National Political Movement (Nairobi) were organized to champion the cause for the NFD's unification with the Somali Republic. On the other hand, the Northern Province People's National Union, the Galla Political Union (Nairobi) and the United Ogaden Somali Association (Nairobi and Garissa) were organized to oppose any union with Somali Republic. The former were better organized and represented the aspirations of the majority of the people in the area. ${ }^{5}$

The development of modern nationalist politics reflected the nature of the relations between the larger colonial state and the region; furthermore, the minority faction in the area that opposed unification with Somalia would not only become reliable agents of central government but would also influence administrative policies in their own interest and to preserve the status quo. As agents of the central government, these "collaborators" took upon themselves the delicate task of balancing the conflicting interests between thestate and "their limited constituency." Whether or not it was by their own volition, this group was promoted as the "legitimate" voice of the Somali population in the country. 
During the Lancaster House Constitutional Conference on Kenya's independence (February-April 1962), the thorny issue of Somali selfdetermination was raised by members of the NFD and Somali delegations. The NFD delegation and the Somali government, the latter not officially a party to the conference, demanded that the NFD question be addressed before Kenyan independence. As Castagno points out, the NFD and Somali government

\begin{abstract}
insisted that the responsibility for settlement was exclusively Britain's and that the Somali claims should by no means be used by Britain to retard the granting of Kenyan independence. KANU and KADU categorically rejected the secessionist proposal, and some members of KANU rejoined that the Somalis in the NFD could emigrate to Somalia if they did not want to accept Kenyan administration. KADU's members alleged that the dominant view in the NFD favoured a Kenyan regional government of the type advocated by $K A D U$ 's leaders. Ethiopia also interposed her views. She supported the Kenyan leaders and exerted pressure on the British government to reject the Somali claim, on the ground that acquiescence to Somali expansionism would lead to "balkanization" of the area. Thereafter, vitriolic exchanges between Somalia and Ethiopia and intermittent border clashes increased the tension that had long marked the Somali-Ethiopian border question.... President Aden Abdullah Osman of Somalia presented his government's view that self-determination-when employed to unify and enlarge an existing state (as in the Somali case)-could not be regarded as balkanization. ${ }^{6}$
\end{abstract}

British Colonial Secretary Reginald Maudling responded to the NFD-Somali request by announcing on April 6, 1962 that a commission would be appointed to inquire into the state of public opinion in the NFD.7 In December 1962, the commission's report was conclusive. It stated that the majority of the people overwhelmingly supported the unification of the area with Somalia. However, the British government acrobatically violated the spirit and the findings of the commission; it quickly rushed through its own Report of the
Regional Boundaries Commission. The latter report deliberately recommended keeping the area within Kenyaby simply redrawing regional borders. ${ }^{8}$ According to the Somali government, Britain's reversal of policy on this matter was due to pressure from Ethiopia against reunification and the concession both Britain and the Kenya African National Union (KANU) made over the question of white settlers in Kenya. ${ }^{9}$ Betrayed by Britain's move, the Somali government severed diplomatic relations with the U.K. on March 18, 1963. Similarly, the majority of the inhabitants of the area rejected the new border policy and intensified its armed struggle against the colonial regime. To counter the heightened insurgency activities in the area, a state of emergency was declared less explicit was the resolution on Somaliland, which stated that "the Conference supports the struggle of the Somali people for their independence and recognizes their right to selfdetermination." The omission of any reference to Somali unity is significant, but the reference to "the right to selfdetermination" was ambiguous, and could be interpreted as implying support for secession as an expression of selfdetermination. ${ }^{10}$

The Conference of Independent African States in April 1958 was far less compromising on the general questions of boundary and the reunification of national groups divided by colonialism. In his summary of the conclusions of the conference, President Nkrumah of Ghana pointed out that: "Ourconference

\section{To counter the heightened insurgency activities in the area, a state of emergency was declared as Kenya obtained independence. In short, Kenya's independence did not mean freedom from subjugation and harassment in the area.}

as Kenya obtained independence. In short, Kenya's independénce did not mean freedom from subjugation and harassment in the area.

The struggle for the unification of a Somali nation was also pursued through regional and continental bodies. As a matter of fact, Somalia attempted to identify its quest for unity through the broader quest for pan-Africanism. The Somali question, however, received mixed support, partly reflecting the ideological divide between the radicals and the moderate camps among nationalist politicians. Saadia Touval made the following observation on the First Afro-Asian Peoples Solidarity Conference in Cairo, December 1957:

Most explicit in its endorsement of irredentist claims was the resolution on Morocco, which stated that "the Conference strongly supports the demand of Morocco for the return of areas still dominated by imperialism in order to ensure the unity and complete independence of Morocco"... Somewhat came to the conclusion that in the interests of that Peace which is so essential, we should respect the independence, sovereignty and territorial integrity of one another...."11 The All-African Peoples Conference in December 1958 sounded another conflicting position:

\section{Be it resolved and it is hereby resolved that All-African Peoples Conference that the Conference: (a) denounces artificial frontiers drawn by imperialist Powers to divide the peoples of Africa, particularly those which cut across ethnic groups and divide people of the same stock; (b) call for the abolition or adjustment of such frontiers at an early date; (c) calls upon the Independent States of Africa to support permanent solution to this problem founded upon the true wishes of the people..... ${ }^{12}$}

However, with the founding of the Organization of African Unity (OAU) in 1963 , the pendulum finally swung in favour of the commitment to territorial integrity and respect for existingnational borders. ${ }^{13}$ Thus, contrary to previous 
rhetoric about the illegitimacy and artificiality of colonial borders, the OAU showed that African leaders were not willing to relinquish their territorial possessions. To be sure, the OAU agreed that borders of postindependence African states were artificial. However, at the same time it maintained that the survival of the borders is preferable to the endless problems that would come up once they are critically questioned..$^{14}$ This position, which supports the status quo, is part of the larger commitment in theory to the principle of noninterference in the domestic affairs of other African states. In this context, self-determination by Somalis in Kenya (North-Eastern Province), Ethiopia (Ogaden and sections of the Haud and Bale) and Djibouti (Afar and Issa regions of the former French Somaliland) or by any other group is regarded as illegitimate and illusionary.

In postcolonial Kenya, armed encounters continued between the Kenyan security forces and loosely organized Somali groups (referred to as Shiftas or "bandits" by the Kenyan government). The latter were supported directly and indirectly by the Somali government. It is reported that between 1964 and 1967, some 2,000 Somalis were massacred by Kenyan security forces. ${ }^{15}$ Accordingly, the OAU intervened to negotiate what it preferred to consider exclusively as a border dispute between Kenya and Somalia. After the OAU summit in Kinshasa, a negotiated armistice between the two states was reached under the chairmanship of President Kenneth Kaunda of Zambia in October $1967 .{ }^{16}$ Although the negotiated settlement scaled down hostilities between the two states and halted the four-year revolt in northeastern Kenya, the question of Somali unification, which was the root of the crisis in the Horn of Africa, was left unresolved. According to Africa Contemporary Record, the settlement also meant different things to Kenya and Somalia:

In a public speech on October 20, President Kenyatta referred to the dispute as "a little quarrel" which had been reconciled, and announced a relaxation of the 5-year state of emergency in the North-Eastern Province. In contrast with this, Prime Minister Egal, speaking to the majority political party in Mogadishu on October 14, said that his Government's policy was to 'stand on one leg ready for war and with the other ready for peace. ${ }^{17}$

Pressure for the unification was kept aliveby various Somaligroupsineastern Africa. In mid-1974 the United Liberation Front of Western Somali handed a memorandum to delegates at the OAU Summit in Muqdisho, demanding the return of the disputed territory to Somalia. The response to the memorandum by the attorney general of Kenya, Charles Njonjo, summarized the familiar official view of the government: "Kenya could never agree to surrender were aggravated by superpower involvement and rivalry in the region. To be sure, border clashes based on the Somali question had been sporadic and all previous engagements had been won by Ethiopia. After the overthrow of the civilian regime of Prime Minister Ebrahim Egal in October 1969, the new military regime in Somalia moved swiftly to reorganize its military capability to surpass that of its opponent, Ethiopia. In 1974, Somalia signed a Treaty of Friendship and Cooperation with the Soviet Union, which also allowed the Soviet Union to build extensive military facilities at Berbera on the Red Sea coast. The treaty alarmed the West- "conservative Arab regimes" across the Red Sea and Kenya. The threat

\section{Tensions between Kenya and Somalia, however, were soon overshadowed by a more profound conflict between Ethiopia and Kenya, the Ogaden war. This war was a result of both internal and external contradictions.}

part of her territory. Kenyans, be they Borans or Somalis, who did not support Kenya 'should pack their camels and go to Somalia'."18 While the message and the tone were not new, the implications for the inhabitants of the area, however, were significant. Expelling inhabitants of the area to Somalia became a strategy for resolving the question of selfdetermination. Even peaceful and democratic dissent to government policies in the area would now be lumped with other forms of dissent, so that anyone partaking in any form of dissent in the region would be seen as an "enemy" of the state. This reinforced the image of the inhabitants of the area as "aliens," whose loyalty to Kenya was always questionable.

Tensions between Kenya and Somalia, however, were soon overshadowed by a more profound conflict between Ethiopia and Kenya, the Ogaden war. This war was a result of both internal and external contradictions. Local conflicts arising from long and uncompromising territorial disputes between Somalia and Ethiopia this treaty created was aptly summarized by the U.S.: "the strategic Gulf to Cape route had now fallen under the Soviet threat." 19

Ethiopia, which had granted the United States facilities at the Kagnew Base outside Asmara and had benefited from enormous U.S. military assistance since the 1950s, faced a serious sociopoliticalcrisis following the October 1974 military coup/revolution. ${ }^{20}$ Specifically, the struggles between the Ethiopian left and the Dergue from 1975 to 1978 led to a reign of terror in the country. The crisis in Ethiopia, therefore, provided the regime in Somalia with a somewhat false opportunity to attempt a military solution to the Somali question by annexing the Ogaden. ${ }^{21}$

As it is now well known, the superpowers dramatically changed client states - the U.S. backed Somalia and the Soviet Union backed Ethiopia. With one of the largest armament airlifts in contemporary African history, the Soviet Union and Cuba made it possible for Ethiopian troops to route the Somalian military in the Ogaden in 
$1978 .{ }^{22}$ When the war ended in July 1979 , President Moi of Kenya visited Ethiopia and, in turn, President Mengistu of Ethiopia visited Kenya in December 1980 in a move to strengthen the defence cooperation between the two states. The fact that the Kenyan government was at that time promoting a fervent antiMarxist, anticommunist ideology, while the Ethiopian government was using Marxist dogma to purge government bureaucrats and opponents who were branded as "capitalist roaders," did not appear to deter the two governments from strengthening relations. In fact, their mutual opposition to the Somali government's territorial claims and to Somali nationalism within their respective territories were clearly major points of agreement around which forms of cooperation could be worked out. This should not come as much of a surprise, however, for anti-Marxist dogma in Kenya and anticapitalist dogma in Ethiopia were used respectively as ideological weapons for silencing or bludgeoning political opposition. One regime might find the other's political program unpalatable, but the tacit agreement demonstrated in these actions is that it does not matter what ideology one side or the other is using, as long as it is meant to achieve the same ends.

The fact that Kenya and Somalia had a common arms supplier (the United States) and similar U.S. military bases on their soil did not disturb the KenyaEthiopia anti-Somalia alliance. To be sure, the U.S. did not support Somalia's border claims and quest for "Greater Somalia." The stated U.S. position was that provision of armaments to Somalia were "conditional upon a nonaggressive posture towards Kenya by Somalia." Tensions between Kenya and Somalia were thereby reduced. ${ }^{23}$ The strategic regional aspirations of the major players in the Cold War had superseded the aspirations of Somalis who were struggling for unification. As far as Kenya was concerned, Somalia's failed adventure in the Ogaden was a clear reminder of the determination of the regime in Muqdisho to realize its vaulting ambitions through whatever means, including infiltrating north- eastern Kenya. Convinced that there was a real and potential threat there, the Kenyan government increased its coercive military presence in the area. ${ }^{24}$

While the growth of superpower involvement in the region (including in Egypt and the Sudan) from the 1970s until the demise of the Soviet Union may have been primarily attributable to the region's strategic position in relation to the oil-producing Middle East, clientstates faced with enormous internal problems encouraged the superpowers to expand their rolein the region. Writing in 1984, Peter Woodward pointed out that:

Troubled client-states may expect help from their external patrons to deal with political and economic difficulties: indeed, these may be presented in such a light as to actively encourage the involvement of the super-powers. Allegations that subversive activities in the domestic arena are being organised by "communists and revolutionaries" on the one hand, or "feudalists and capitalist lockeys" on the other, quickly become the language of describing opposition threats, however far they may be removed from the real complexities of the political and economic problems faced by most states in the region. ${ }^{25}$

Although superpower involvement in local politics led to increased state repression, increased violations of human rights and increasing numbers of refugees, external support sustained the regimes of Ethiopia, Somalia and Kenya, each of which were facing a crisis of legitimacy on the domestic front.

In the 1980s border incidents and general insecurity in the North-Eastern Province provoked severe military retribution. Kenyan security forces responded with brutal military operations in the area, following an ambush in which a Kenyan government officer waskilled in June 1981. In another incident in early 1984, the army massacred some 400 civilians. ${ }^{26}$ On February 20, 1989 the Kenyan government reported that Somalia armed forces invaded the Sebule border area, wounded a number of Kenyans and killed six elephants. ${ }^{27}$ In September 1989 the Kenyan government reported that four
Kenyan policemen were killed, four other people were injured and some policemen were captured, following an attack on the small town of Garissa by Somalia armed forces. ${ }^{28}$ Kenya's security forces reacted to these incidents by using force totally out of proportion with the level of threat that the Somali dissidents posed to the security of the area. Violence was employed arbitrarily, unpredictably and brutally against people who were deemed "enemies" of the state. Perhaps the Kenyan government's strategy was to deter future disturbances in the area.

By 1989 the political situation in Somalia was leading to civil war, social disintegration and the collapse of the state. In response, the Kenyan government shifted its focus from "troubles

\section{Violence was employed arbitrarily, unpredictably and brutally against people who were deemed "enemies" of the state.}

originating" from Somalia to its local poaching problem. The increasing incidence of poaching in Kenya's game parks, particularly in Tsavo, was now allegedly linked to the "agitators" in the North-Eastern Province. Indeed, the recent spate of poaching and killings in the area has been blamed on "indigenous" and "alien" Somalis. Ironically, while similar incidents in other parts of Kenya are treated as isolated cases of crime, in the NorthEastern Province or adjacent areas they are often treated as part of deliberate political and economic strategies to destabilize the nation and discourage tourism. The incident of September 5, 1988 , in which twelve travellers were killed and twenty-nine others injured when three buses were attacked between Gartuba and Bangale, is a case in point. ${ }^{29}$ Accordingly, the government attempted to save its troubled tourist industry by appointing Dr. Richard Leakey to implement its nationwide shoot-to-kill policy against poachers. However, since 
the government had presented Somalis as poachers, this policy was interpreted by some Kenyan-Somalis as an official strategy to legitimize the massacre of their people. ${ }^{30}$

In November 1988 the MP for Dujis in Garissa District and Minister of State Hussein Maalim Mohammed, stated that aliens from a neighbouring country (Somalia) had infiltrated the country and were illegally acquiring citizenship and engaging in dubious business. In 1989 the Kenyan government began screening ethnic Somalis in the country. The Weekly Review (November 17, 1989) made this observation:

The current screening of ethnic Somalis in Kenya may, on the face of it, appear unusual, but those anxious for an explanation probably need not go much further than the deterioration in recent months of the security situation in NorthEastern Province and surrounding areas.... If the intention of the current screening exercise of ethnic Somalis is to root out rebels whom Barre complains have sought sanctuary in the country, then the Somali government has every reason to be pleased. As for local Somalis, some of them may find the exercise inconvenient, and probably even a discriminatory one. But the security factors involved appear to have led the Kenya government to decide that the move was imperative. Being a neighbour of Somalia and having a sizeable ethnic Somali population within its borders, Kenya can barely escape some consequences of the internal strife in Somalia. ${ }^{31}$

The image of Somalis seen in the larger historical context of conflicts between the two states and between the central government and the NorthEastern Province have blurred the distinction between Somali refugees and Kenyan-Somalis. As a matter of fact, the distinction is often arbitrary, and this has affected the lives of all Somalis in Kenya. Africa Watch had this to say:

State of emergency laws in the North Eastern Province allow security forces to detain anyone for up to 56 days without trial. An umbrella charge of "banditry" has been used ubiquitously in the North Eastern Province to subject a countless number of individuals to harassment, beatings, detention and torture as well as being levied dgainst entire village communities as an official platform tocarry out violent security sweeps. There have been a number of massacres by Kenyan security forces in the North Eastern Province condemned as gross violations of human rights by the international organizations-in Garissa 1980, Modgashe 1982, Pokot 1984, Wajir 1984 and Wajir 1987.... In 1987 another incident in Wagala, near Wajir, resulted in at least 297 people massacred, although the government only acknowledged 57 dead claiming "inter-tribalclashes." The killing followed a systematic operation by the security forces who confiscated thousands of identity cards and closed all water sources in Wajir, a desert region. Eyewitness reports told of people forced to strip, detained in barbed wire enclosure and deprived of food and water. Groups of peoplewere burned alive with petrol; others were shot or beaten to death. ${ }^{32}$

In its opposition to government repression of Kenyan-Somalis and the forcible repatriation of Somali refugees, Africa Watch argued that:

The Kenyan authorities are also using the influx of Somalis seeking sanctuary to impose a discriminatory and repressive screening process on its own ethnic Somali community, which has suffered a history of persecution.... Some 3,000 refugees staying in makeshift shelters in Liboi, North Eastern Kenya, received no food or assistance from the Kenyan authorities sincearriving in Kenya on September 20.... The refugees were harassed and beaten by Kenyan security forces, and three arrested for "inciting resistance" against deportation. All refugees have now reportedly been returned to areas in Somalia where heavy fighting persists, or have fled to escape forcible repatriation.... The authorities have increased security sweeps and identity checks of Kenyans of Somalioriginand Somalis living in Kenya. The arrival of the refugees is being used as an opportunity to impose compulsory screening on all Kenyan-Somalis, in order to identify "illegal aliens." 33

It is also imperative to indicate that the unstated policy of "refugee deterrence," which often means discouraging refugee influx by forcing refugees to go to the overcrowded camps and/or inducing involuntary repatriation, affects the treatment of refugees in general. Sending refugees to overcrowded camps, however, also reflects the lack of resources available to provide needed assistance to refugees. As a matter of fact, the severe ecological, political and economic crises the country faces have direct implications for refugees in the country. With thousands of internally displaced persons (products of political or "ethnic" violence) and hundreds of thousands facing famine due to drought, the government of Kenya does not have the capacity to meet the basic human rights needs of an estimated 700,000 refugees now living within Kenya (most of whom are Somali refugees).

The Kenyan government needs to radically change its inhumane treatment of Kenyan-Somalis and Somali refugees. This will mean that the state should adhere tointernational humanrights and refugee covenants it endorsed. Also, it should develop a refugee determination mechanism that will make a clear distinction between Kenyan-Somalis and Somali refugees. Equally important, Kenya and other OAU member states must find a democratic way of addressing the question of the state's political legitimacy. The question of protecting and meeting minority ethnic groups' aspirations can no longer be avoided by Kenya and the OAU.There is an urgent need for the international community to address the crisis in Somalia to save the loss of human lives and allow for a speedy repatriation of Somali refugees. Assistance to refugees in Kenya may be directed to the UNHCR, African Medical and Research Foundation, Médecins San Frontières, All-African Conference of Churches, Church of the Province of Kenya, National Council of Churches of Kenya/ Refugee Service Unit, International Committee of the Red Cross, Kenya Red Cross Society, Jesuit Refugee Service in Africa and Kenya Catholic Secretariat.

\section{Notes}

1. U.S. Committee for Refugees, World Refugee Survey (1991): 44-45; U.S. Committee for Refugees, World Refugee Survey (1992): 43-45; Africa Watch 
(November 17, 1989). See also World Refugee Survey (1987): 38.

2. A.A. Castagno, "The Somali-Kenya Controversy: Implications for the Future," Journal of Modern African Studies 2, no. 2 (1964): 165-69.

3. Ibid., 70-71.

4. Ibid.

5. Ibid.

6. Ibid., 176-77.

7. See Somali Government, The Issue of the Northern Frontier District (Muqdisho: Somali Government, 1963): 19.

8. Report of the Northern Frontier District Commission, presented to Parliament by the Secretary of State for the colonies by command of Her Majesty (London: HMSO, 1962); Kenya Colony and Protectorate: Report of the Regional Boundaries Commission (London: HMSO, 1962).

9. Somali Government, Frontier Problem Planted by Britain between Kenya and Somali Republic (Muqdisho: Somali Government, 1963).

10. See Saadia Touval, The Boundary Politics of Independent Africa (Cambridge: Harvard University Press, 1972): 52-53.

11. Ibid., 54.

12. Ibid., 56-57.

13. See Crawford Young, "Self-Determination, Territorial Integrity, and African State System," in Conflict Resolution in Africa, edited by Francis M. Deng and I. William Zartman (Washington, D.C.: The Brookings Institution, 1991): 327; John Ravenhill, "Redrawing the Map of Africa," in The Precarious Balance: State and Society in Africa, edited by Donald Rothchild and Naomi Chazen (Boulder: Westview Press, 1988): 282-306; Harvey Starr and Benjamin A. Most, "Contagion and BorderEffects on Contemporary African Conflict," Comparative Political Studies 16, no. 1 (April 1983): 92-117.

14. See Peter Woodward, "Relations Between Neighbouring States in NorthEast Africa," Journal of Modern African Studies 22, no. 2 (1984): 280.

15. Gundrun Dahl, Suffering Grass: Subsistence and Society of Waso Borana (Stockholm: Studies in Social Anthropology, 1979): 200.

16. See Nzongola-Ntalja, "The National Question and the Crisis of Instability in Africa," in Africa: Perspectives on Peace and Development, edited by Emmanuel
Hansen (London and New Jersey: The United Nations University, 1987): 55-86; Chege, "Conflict in the Horn of Africa," in Africa: Perspectives on Peace and Development, edited by Emmanuel Hansen (London and New Jersey: The United Nations University, 1987): 87-100; W. Scott Thompson and I. William Zartman, "The Development of Norms in the African System," in The Organization of African Unity After Ten Years, edited by Yassin El-Ayouty (New York: Praeger Publishers, 1975): 5-6.

17. See Africa Contemporary Record (London, 1968-69): 159.

18. Africa Contemporary Record (London, 1974-75): B209.

19. Chege, "Conflict in the Horn of Africa," 91.

20. Bereket H. Salassie, "The Dilemma on the Horn of Africa," Journal of Modern African Studies 22, no. 2 (1984): 260.

21. Ibid., 272.

22. See, for example, Keith Sommerville, Foreign Military Intervention in Africa (London: St. Martin's Press, 1990): 41-60; I. William Zartman, Ripe for Resolution: Conflict and Intervention in Africa (Oxford: Oxford University Press, 1985): 71-117.

23. Chege, "Conflict in the Horn of Africa," 94.

24. For a useful theoretical debate on state repression, coercion and terror, see David Pion-Berlin, The Ideology of State Terror (Boulder and London: Lynne Reinner Publishers, 1989): 1-7; Ekkart Zimmermann, Political Violence, Crises, and Revolutions: Theories and Research (Boston: G.K. Hall \& Co., 1983).

25. Woodward, "Relations Between Neighbouring States in North-East Africa," 283.

26. Chege, "Conflict in the Horn of Africa," 93.

27. SeeNairobi-based newspapers, Standard, Daily Nation and Kenya Times (February 21, 1989).

28. See "Terror Reigns in Eastern Kenya," Weekly Review (Nairobi, n.d., 1992):21-22.

29. Weekly Review (Nairobi, November 12, 1989): 19-20.

30. Personal interview with a KenyanSomali, Mombasa, June 23, 1992.

31. Weekly Review (Nairobi, November 17, 1992).

32. Africa Watch (November 17, 1989): 10-11.

33. Ibid.
Research, Conference and Travel Grants

\section{CENTRE FOR} REFUGEE STUDIES York University

CRS grants are intended to assist and encourage research on "refugee and development" ways of understanding and resolving refugee problems in developing countries.

This includes support for research activities on the following topics:

- Refugee settlement in less developed countries

- Repatriation and development in less developed countries

- Forces affecting refugee generation in less developed countries

- Global changes and policies in sending and receiving countries as well as activities of international agencies that will affect refugee generation and development efforts.

Applications are considered twice a year. Completed applications must be received by November 15 and March 15 for funding decisions by January 15 and May 15 respectively.

For further details, please contact:

Helen Gross

Student/Faculty Liaison

Centre for Refugee Studies

Suite 322, York Lanes

York University

4700 Keele Street

North York, ON

Canada M3J 1P3

Tel: (416) 736-5663

Fax: (416) 736-5837

E-mail via BITNET, address:

REFUGE@YORKVM1 